\title{
Optimalisasi Masyarakat Desa Dalam Menghadapi Tanggap Darurat Pandemi Covid-19
}

\author{
Elfirda Ade Putri ${ }^{1,}$, , Slamet Pribadi ${ }^{1}$ \\ ${ }^{1}$ Fakultas Hukum; Universitas Bhayangkara Jakarta Raya; Jl. Perjuangan 081, Marga Mulya, \\ Bekasi Utara; Telp. 02188955882/ +622188955871; e-mail: elfirdade.putri@gmail.com, \\ slametpribadi_99@yahoo.com \\ * Korespondensi: e-mail: elfirdade.putri@gmail.com
}

\begin{abstract}
The lack of public awareness of the implementation of the Covid-19 health protocol has made the spread of Covid-19 even more massive, for example on December 1, 2020 in our country Indonesia has reached 543,975 positive cases with 17,081 deaths and 454,879 recoveries and if we refer to the data on CoronaVirus cases in the world, it has reached 2,500 cases. positive $63,315,184$ with 1,469,835 deaths and 40,602,957 recoveries. The data was obtained from the Johns Hopkins Coronavirus Resource Center. This activity provides education to the people of Lubang Buaya Village on the importance of wearing masks, washing hands and maintaining distance as well as providing education to the community about the dangers of the Covid-19 virus and providing benefits to the community on the importance of preventing the spread of Covid-19 in the form of counseling.
\end{abstract}

Keywords: Optimization, Pandemic, Response

\begin{abstract}
Abstrak
Kurangnya kesadaran masyarakat akan penerapan protokol kesehatan Covid-19 membuat penyebaran Covid-19 semakin masif contohnya pada tanggal 1 Desember 2020 di negeri kita Indonesia telah mencapai kasus positif 543.975 dengan kematian 17.081 dan kesembuhan 454.879 dan jika mengacu pada data kasus CoronaVirus di dunia telah mencapai kasus positif 63.315.184 dengan kematian 1.469,835 dan kesembuhan 40.602,957. Data tersebut didapat dari sumber Johns Hopkins Coronavirus Resource Center. Kegiatan ini memberikan Edukasi terhadap masyarakat Desa Lubang Buaya pentingnya memakai masker, mencuci tangan dan menjaga jarak serta memberikan penyuluhan kepada masyarakat terhadap bahayanya virus Covid-19 dan memberikan manfaat kepada masyarakat akan pentingnya mencegah penyebaran Covid-19 berupa penyuluhan.
\end{abstract}

Kata kunci: Optimalisasi, Pandemi, Tanggap

\section{Pendahuluan}

Abdimas merupakan proses pembelajaran bagi Mahasiswa S1 Universitas Bhayangkara Jakarta Raya yang dikembangkan melalui Kegiatan Pengabdian kepada Masyarakat dalam berbagai segi kehidupan bermasyarakat. Pelaksanaan Abdimas ditunjukan untuk menumbuh kembangkan empati dan kepedulian civitas akademika Universitas Bhayangkara Jakarta Raya terhadap (1) Berbagai permasalahan yang riil dihadapi masyarakat (2) pembangunan berkelanjutan yang diperlukan untuk mencerdaskan kehidupan bangsa dan mewujudkan kesejahteraan masyarakat yang sesuai dengan masyarakat yang peduli kepada 
sesama.

Selain itu, pelaksanaan abdimas diharapkan melahirkan pribadi yang Tangguh, unggul, berkepribadian mulia, serta dapat menjadi pribadi yang luar biasa ketika sudah terjun dimasyarakat, berjiwa kepemimpinan, untuk itu Universitas Bhayangkara Jakarta Raya telah mengembangkan kegiatan abdimas yang tidak hanya berisi kegiatan kerja civitas akademika Ubharajaya untuk masyarakat, tetapi berisi rangkaian kegiatan integrative interdisipliner yang dikemas secara strategis untuk menyelesaikan permasalahan secara tuntas dan dilaksanakan bersama masyarakat dengan memerankan masyarakat sebagai pelaku penting dan utama serta melibatkan para pemangku kepentingan lain yang terkait. Berperan sebagai problem solver, motivator, fasilitator dan dinamisator dalam proses penyelesaian masalah dan pembangunan/ pengembangan masyarakat. Melalui pembaruan konsep tersebut kehadiran mahasiswa sebagai intelektual muda diharapkan mampu mengembangkan diri sebagai agen atau pemimpin perubahan yang secara cerdas dan tepat menyelesaikan masalah yang dihadapi masyarakatnya.

Pada dasarnya Abdimas merupakan bentuk pengabdian nyata kepada masyarakat. Dalam kegiatan pengabdiannya pada masyarakat, mahasiswa memberikan pengalaman ilmu pengetahuan, teknologi, seni dan agama untuk memberikan pengarahan agar dapat memecahkan masalah dan menanggulanginya secara tepat. Dengan kata lain, melalui ABDIMAS ini, mahasiswa membantu mengoptimalisasi masyarakat Desa Lubang Buaya dalam Menghadapi Pandemi Covid-19 yang terletak di Kecamatan Setu khususnya di Desa Lubang Buaya. Meninjau tentang Desa Lubang Buaya yang berada di kecamatan setu. Desa Lubang buaya adalah salah satu desa yang berada dalam wilayah Kecamatan Setu, Kabupaten Bekasi, Provinsi Jawa Barat, Kode pos 17320. Desa Lubangbuaya terdiri dari 3 Dusun, 19 Rw dan 101 Rt. Kecamatan Setu merupakan salah satu dari 23 kecamatan yang ada di wilayah Kabupaten Bekasi. Kecamatan Setu letaknya di daerah selatan Bekasi, tepatnya berbatasan langsung dengan kecamatan Cileungsi Bogor di bagian selatan dan kecamatan Bantar Gebang Kota Bekasi di bagian barat.dan Kecamatan Cikarang Selatan dan serang Baru di bagian timur. Kecamatan Setu terdiri dari 11 desa yaitu Desa Burangkeng, Cibening, Cijengkol, Cikarageman, Ciledug, Kertarahayu, Lubang Buaya, Muktijaya, Ragemanunggal, Taman Rahayu, dan Taman Sari. Lubang Buaya adalah desa yang bersuku Betawi, sedangankan 8 desa di wilayah selatan adalah desa yang bersuku Sunda. Dapat di jelaskan bahwa batas wilayah desa Lubang Buaya adalah Desa Lambang Jaya di sebelah utara, Desa Mekarwangi di sebelah selatan, Desa Cibuntu di sebelah timur dan Desa Cijengkol di sebelah barat. Sebelum Desa ini dinamakan Desa Lubang buaya, desa ini bernama Desa Tanjung Jaya. Yang meliputi 4 desa, yaitu diantaranya : Desa Cijengkol, Desa Telajung, Desa Cikedokan dan Desa Lubangbuaya menjadi satu desa. Terdapat kantor desa yang beralamat di Jl. Lubang Buaya No.1, Lubangbuaya, Kec. Setu, Bekasi, Jawa Barat 17320.

Daerah ini merupakan salah satu daerah penghasil komoditas perkebunan, diantaranya rambutan dan salak serta melinjo. Sedangkan untuk pertanian, berupa tanaman padi, tidak 
terlalu berpotensi karena di daerah ini pegairannya hanya mengandalkan curah hujan.Bisa di sebut daerah tadah hujan.Lebih banya ladang dari pada sawahnya. Di daerah ini pula belum ada industri besar, namun dibeberapa daerah Setu industri kecil mulia tumbuh. Bahkan,pada masa orde baru ada satu daerah di kecamatan Setu yang dijadikan sebagai pusat industri kerajinan imitasi, namun di era sekarang ini, pusat industri kecil tersebut kondisinya lesu.

Covid-19 merupakan penyakit yang disebabkan oleh virus corona. Virus ini menyerang saluran pernapasan. Gejala Covid-19 yang paling umum adalah deman, kelelahan, dan batuk kering. Beberapa orang mengalami sakit dan nyeri, hidung tersumbat, pilek, sakit tenggorokan, diare. Untuk proses penularan terjadi orang ke orang sehinnga perlu adanya pencegahan yang harus dilakukan. Adapun cara penanggulangan dan pencegahan yang benar yaitu dengan selalu menjaga pola hidup sehat (makan, tidur, olahraga) untuk umunitas tubuh, rajin mencuci tangan, menjaga etika batuk dan bersin, menghindari kerumunan, menghindari menyetuh mata, mulut, dan hidung, mengurangi interaksi dengan orang lain, berdoa dan lain sebagainya. Sebagai bentuk partisipasi yang dapat yang kita lakukan yaitu dengan mendukung kebijakan pemerintah mengenai sekolah dirumah atau belajar secara online, bekerja dari rumah dan ibadah di rumah. Serta selalu melakukan hal-hal positif yang mampu mengurangi rasa khawatir terhadap maraknya penyebaran virus corona ini. Covid-19 ini tidak boleh disepelekan dan walaupun kita waspada jangan terlalu dipikirkan. Maka dari itu perlu adanya edukasi untuk masyarakat agar dapat memahami Covid-19 dengan adanya edukasi ini maka dapat membantu pengetahuan masyarakat terhadap Covid-19.

\section{Metode Pelaksanaan}

Pelaksanaan kegiatan yang dilakukan, yaitu: a) Sosialisasi kepada masyarakat Desa Lubang Buaya; b) Pemasangan tempat cuci tangan; c) Pemasangan tempat sampah; d) Penyuluhan dewasa; e) Penyemprotan disinfektan.

Pengabdian pada masyarakat yang diterapkan dalam ABDIMAS, dalam pelaksanaannya memiliki sasaran kegiatan pengabdian kepada masyarakat, antara lain: Masyarakat Desa Lubang Buaya. Sasaran kami selanjutnya adalah masyarkat Desa Lubang Buaya Setu. Melalui beberapa program kerja yang telah kami buat serta sosialisasi dan penyuluhan yang telah dilaksanakan, kami berharap masyarakat dapat mampu menjaga kesehatan diri dan lingkungan, serta dapat memahami apa saja protokol kesehatan dalam menjaga keluarga. Kami juga mengedukasi mengenai gejala-gejala Covid-19 serta tindakan yang harus dilakukan jika terpapar, agar menambah wawasan bagi masyarakat Desa Lubang Buaya dan masyarakat dapat lebih peduli dan peka terhadap kondisi kesehatan diri dan keluarganya.

\subsection{Tahap pelaksanaan kegiatan}

Dalam tahapan ini, terbagi menjadi beberapa tahapan, yaitu a) pembukaan kegiatan abdimas; b) pemasangan tempat cuci tangan; c) pemasangan tempat sampah. 
Kegiatan pembukaan pelaksanaan abdimas dilakukan di Kantor Balai Desa Lubang Buaya. Pada hari pertama pelaksanaan pembukaan Abdimas di Desa Lubang Buaya Setu berlangsung pukul 10.00 WIB hingga pukul 12.00 WIB. Dihadiri oleh para peserta. Sosialisasi sebagai bentuik pendekatan diri mahasiswa kepada warga Desa Lubang Buaya dengan perkenalan diri dan memberikan pemahaman secara singkat mengenai Covid-19 dan membagikan masker bagi warga yang ditemui pergi keluar rumah tanpa menggunakan masker.

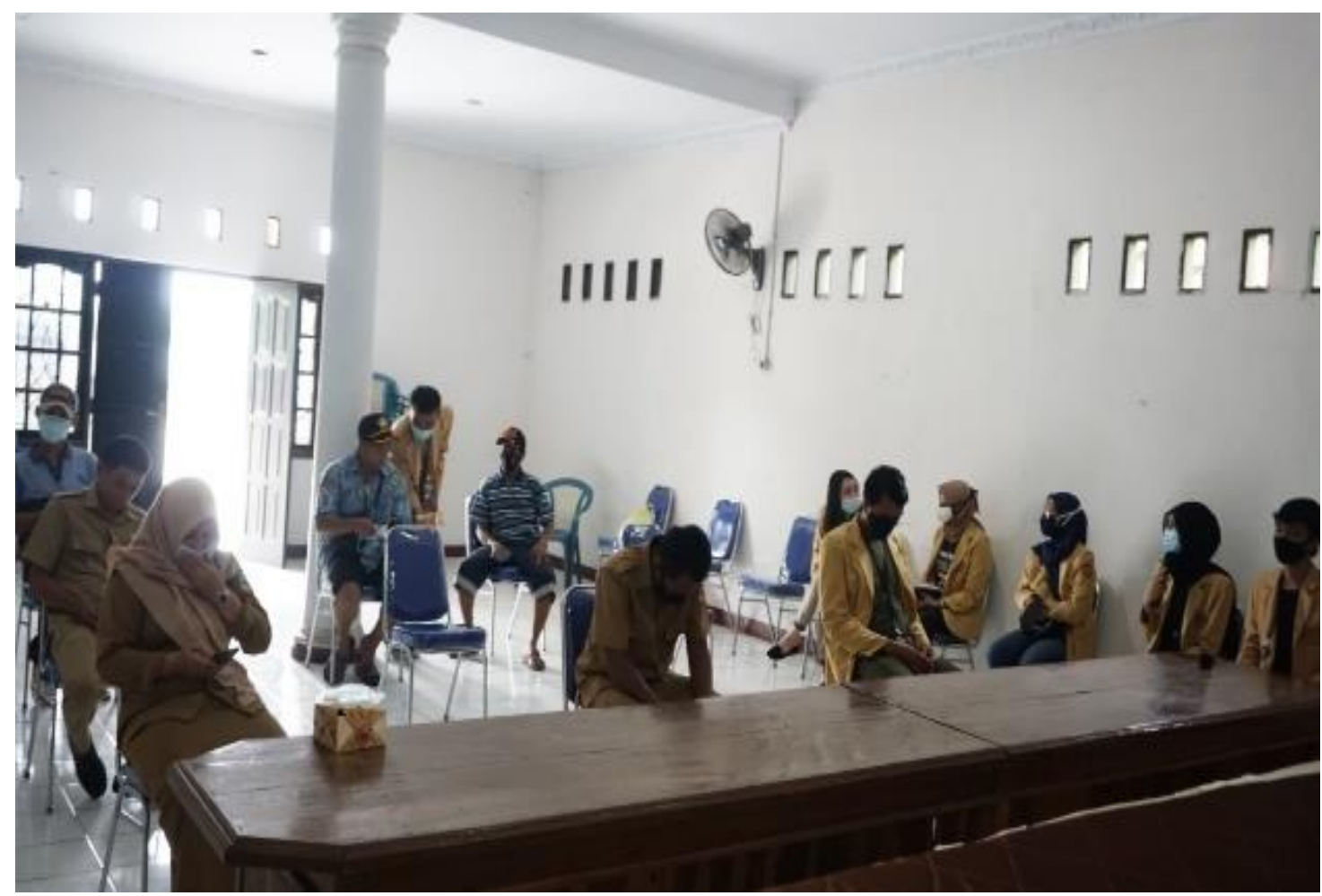

Sumber: Hasil Pelaksanaan (2021)

\section{Gambar 1. Pelaksanaan ABDIMAS}

Kegiatan pemasangan tempat cuci tangan di lingkungan Desa Lubang Buaya dilakukan pada hari selanjutnya Pemasangan tempat cuci tangan portable ditiga sudut desa yang merupakan tempat-tempat yang paling sering dikunjungi atau dilalui oleh masyarakat Desa Lubang Buaya, seperti di Balai Desa, di Masjid, dan juga di pos tempat warga berkumpul. Tempat cuci tangan ini diperuntukan bagi warga agar mengingatkan pentingnya menjaga kebersihan tangan dan mempermudah warga dalam menjaga kebersihan tangannya, sebagai wujud dari pencegahan terhadap virus Covid-19.

Kegiatan ketiga pada pelaksanaan abdimas yaitu pemasangan tempat sampah di Desa Lubang Buaya. Pemasangan tempat sampah didua sudut tempat yang paling sering dilalui warga, guna menjaga kebersihan Desa Lubang Buaya dan untuk meningkatkan kesadaran warga pentingnya menjaga kebersihan lingkungan dengan membuang sampah pada tempatnya. Pemasangan tempat cuci tangan dan tempat sampah sudah sesuai dengan anjuran dari ketua RW setempat. 


\section{Hasil dan Pembahasan}

Berdasarkan hasil Abdimas yang telah dijalankan selama kurang lebih tiga minggu di Desa Lubang Buaya, diperoleh hasil survey melalui metode kuisioner kepada 50 orang warga serta didapati berbagai tanggapan dari warga. Warga Desa Lubang Buaya rata-rata sangat puas dengan diadakannya penyuluhan serta sosialisasi tentang protokol kesehatan dalam upaya pencegahan virus Covid-19 ini. Karena dengan penyuluhan yang telah dilakukan menambah wawasan dan pengetahuan bagi warga mengenai virus ini, rata-rata warga menjadi lebih paham akan cara pencegahan serta gejala-gejala Covid-19 dan mengetahui pentingnya menjaga kebersihan tangan dan penggunaan masker. Dan pemberian tempat cuci tangan serta tempat sampah juga membantu warga dalam menjaga kesehatan diri dan juga menjaga kebersihan lingkungan Desa Lubang Buaya. Berdasarkan evaluasi yang telah dijalankan selama kurang lebih 2 minggu ini terhadap 30 sampai 50 warga Kecamatan Setu, desa Lubang Buaya diperoleh hasil survey melalui pendataan angket secara langsung yang didapatkan berbagai respon yang bervariasi dari warga. Dari respon yang diberikan oleh warga, rata-rata warga sangat puas dengan diadakannya sosialisasi dan penyuluhan hukum mengenai upaya pencegahan Covid-19 yaitu tata cara mencuci tangan yang benar pentingnya mencuci tangan menggunakan sabun, tata cara penggunaan masker yang baik dan benar, serta pembagian masker, handsanitizer, sabun cuci tangan, tempat sampah, galon air, tempat sabun, serta meja.

Hasil survey menunjukkan peningkatan pengetahuan dan pemahaman masyarakat terhadap upaya pencegahan Covid-19. Dari 30 hingga 50 responden terdapat $80 \%$ yang memberikan respon positif dan memahami dengan baik apa yang disosialisasikan. Jika dibandingkan dengan data sebelum diadakannya sosialisasi ini, terjadi peningkatan yang cukup baik terkait pengetahuan dan pemahaman warga terhadap upaya pencegahan Covid-19. Hal ini dapat dilihat pada gambar diagram berikut.

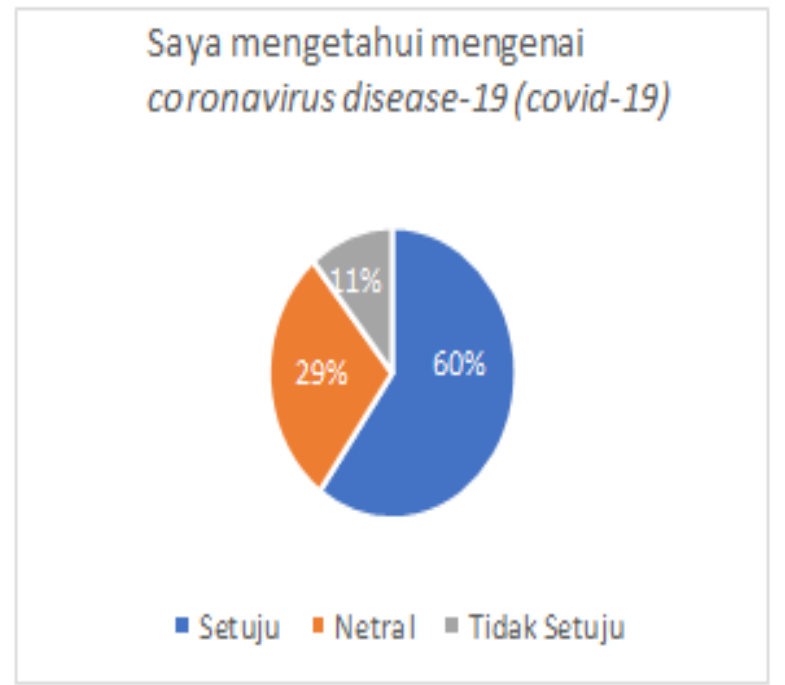

(a) Sebelum Diadakan Sosialisasi

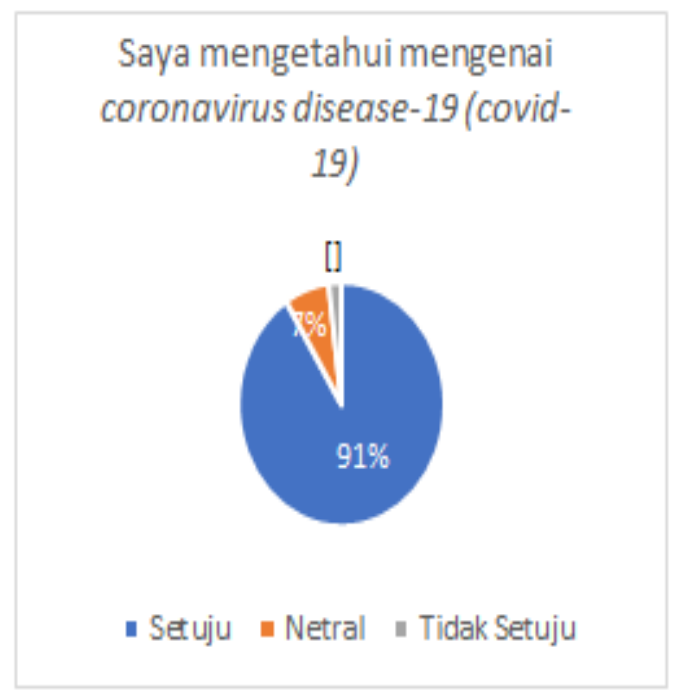

(b) Sesudah Diadakan Sosialisasi

Sumber: Hasil Pelaksanaan (2021)

Gambar 2. Pemahaman Warga Terhadap Pengetahuan Mengenai Covid-19 
Dari diagram terlihat bahwa terjadi peningkatan yang sangat baik terhadap pengatahuan dan pemahaman warga terkait pengetahuan warga mengenai Covid-19. Sekitar 90\% warga RT 01 Kecamatan Setu Desa Lubang Buaya telah memahami segala hal mengenai Covid-19. Namun masih ada sebagian dari warga yang masih belum memahami tentang Covid19. Hal ini disebabkan karena kurangnya pengetahuan dari warga mengenai adanya Covid-19.

Selanjutnya, perbandingan peningkatan pengetahuan dan pemahaman warga terhadap ketakutan mereka terhadap Covid-19, dapat dilihat pada gambar diagram berikut.

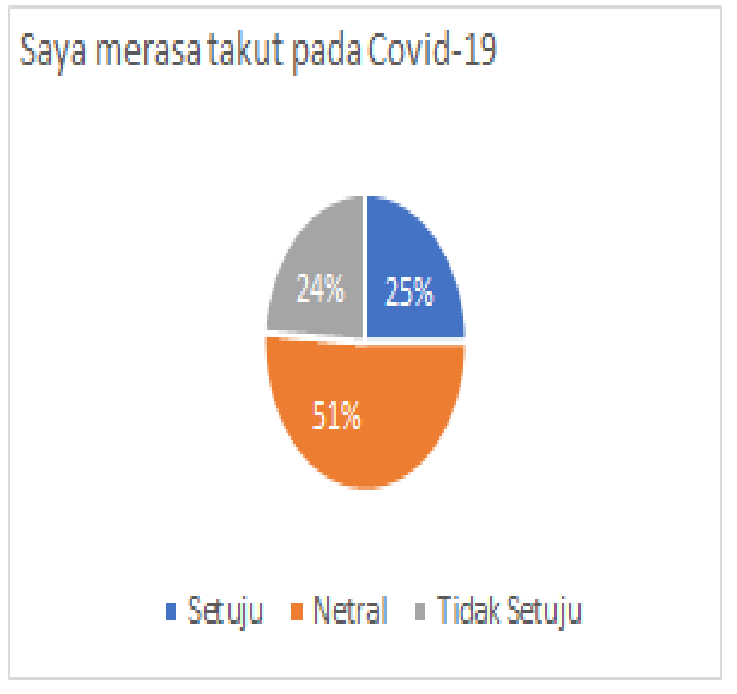

(a) Sebelum Diadakan Sosialisasi

\section{Saya merasa takut pada Covid-19}

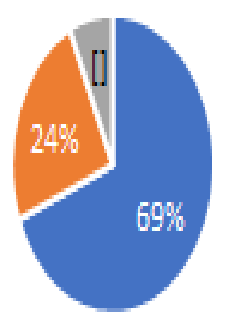

- Setuju | Netral | Tidak Setuju

(b) Sesudah Diadakan Sosialisasi

Sumber: Hasil Pelaksanaan (2021)

Gambar 3. Pemahaman Warga Terhadap Pengetahuan Mengenai Covid-19

Dari data-data diagram terlihat bahwa adanya peningkatan baik itu pemahaman, pengetahuan, maupun kesadaran warga akan bahayanya Covid-19 yang terus menyabar. Hal ini disebabkan karena sebelum diadakannya sosialasasi dan penyuluhan hukum ini masyarakat awam banyak menganggap bahwa Covid-19 tidak berbahaya.

Namun setelah diadakannya sosialisasi ini, mampu mengubah persepsi masyarakat mengenai bahaya Covid-19. Jadi, dapat disimpulkan, dengan diadakannya sosialisasi dan penyuluhan dapat meningkatkan pengetahuan, pemahaman, serta kesadaran masyarakat terkait pentingnya pencegahan Covid-19.

Selanjutnya, perbandingan peningkatan pengetahuan dan pemahaman warga terhadap protocol kesehatan yang harus di terapkan untuk upaya pencegahan Covid-19 yaitu mengenai jaga jarak sosial, pemakaian masker 3 lapis, melakukan cuci tangan, serta menggunakan hand sanitizer. Dari data-data diagram terlihat bahwa adanya peningkatan baik itu pemahaman, pengetahuan, maupun kesadaran warga akan pentingnya penerapan protokol kesehatan (3M) sebagai upaya pencegahan Covid-19 yang terus menyabar, hasil data diagram seperti ditunjukkan pada gambar 4 . 


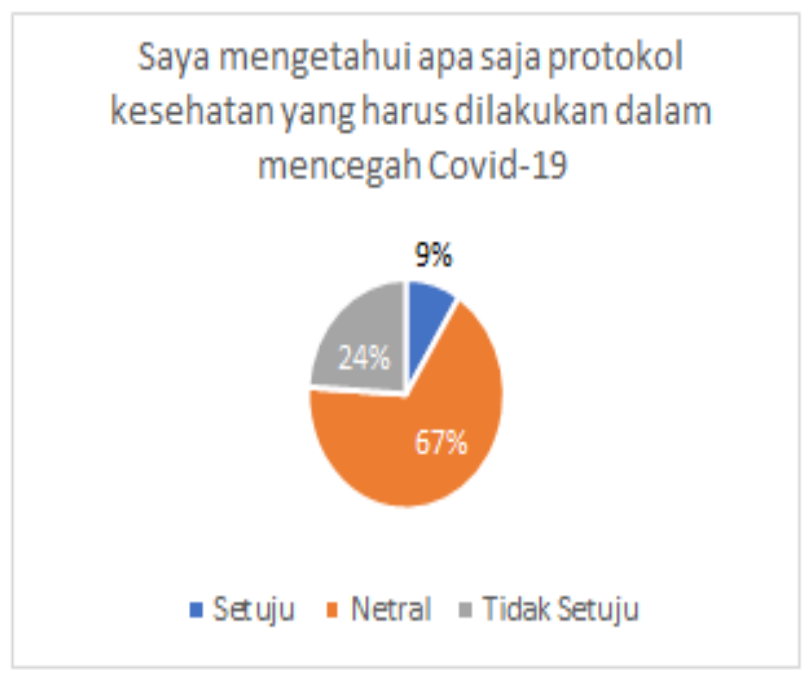

(a) Sebelum Diadakan Sosialisasi

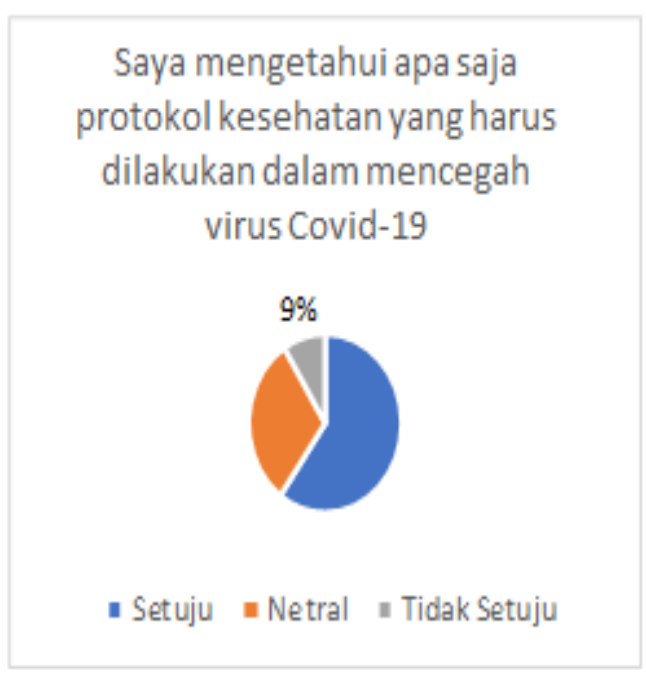

(b) Sesudah Diadakan Sosialisasi Sumber: Hasil Pelaksanaan (2021)

Gambar 4. Pemahaman Warga Terhadap Pengetahuan Mengenai Covid-19

Dari grafik menunjukkan sebelum diadakannya sosialasasi dan penyuluhan hukum ini masyarakat awam banyak menganggap bahwa penerapan protocol kesehatan tidak akan efektif sebagai pencegahan Covid-19. Namun setelah diadakannya sosialisasi ini, mampu mengubah persepsi masyarakat mengenai bahaya Covid-19. Jadi, dapat disimpulkan, dengan diadakannya sosialisasi dan penyuluhan dapat meningkatkan pengetahuan, pemahaman serta kesadaran masyarakat terkait pentingnya penerapan protokol kesehatan untuk pencegahan Covid-19. Selanjutnya, perbandingan peningkatan pengetahuan dan pemahaman warga terhadap gejala-gejala terinfeksi Covid-19 yang harus diketahui untuk upaya pencegahan Covid-19, dapat di lihat pada gambar diagram berikut.

\section{Saya mengetahui gejala-gejala bagi orang yang terinfeksi virus Covid-19}

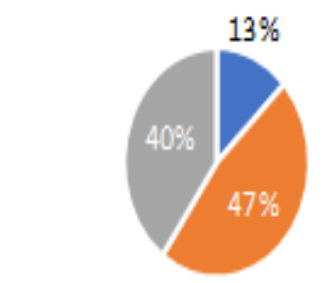

- Setuju = Netral " Tidak Setuju

(a) Sebelum Diadakan Sosialisasi

\section{Saya mengetahui gejala-gejala bagi orang yang terinfeksi vi rus Covid-19}

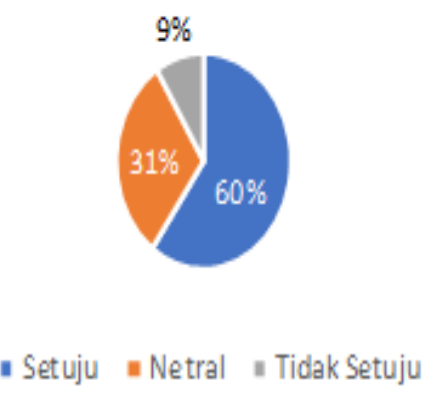

(b) Sesudah Diadakan Sosialisasi

Sumber: Hasil Pelaksanaan (2021)

Gambar 5. Pemahaman Warga Terhadap Pengetahuan Mengenai Covid-19 
Dari data-data diagram terlihat bahwa adanya peningkatan baik itu pemahaman, pengetahuan warga mengenai gejala-gejala yang akan terjadi jika seseorang mulai terinfeksi Covid-19. Hal ini disebabkan karena sebelum diadakannya sosialasasi dan penyuluhan hukum ini masyarakat awam banyak yang tidak paham dan tidak mengetahui perbedaan gejala-gejala jika terinfeksi Covid-19, dengan gejala-gejala yang menunjukan hanya Demam.

Namun setelah diadakannya sosialisasi ini, mampu menjadikan masyarakat menjadi lebih berhati-hati dan memperhatikan pihak ain jika menunjukan gejala-gejala tersebut. Jadi, dapat disimpulkan, dengan diadakannya sosialisasi dan penyuluhan dapat meningkatkan pengetahuan, pemahaman serta kesadaran masyarakat terkait pentingnya menjaga jarak dengan pihak lain, karena kita tidak mengetahui gejala-gejala yang ada, apalagi Gejala Covid19 pun ada yang tidak terlihat. Selanjutnya, perbandingan peningkatan pengetahuan dan pemahaman warga mengenai tindakan apa yang harus dilakukan oleh anggota keluarga jika ada yang terpapar Covid-19, dapat dilihat pada gambar diagram berikut.

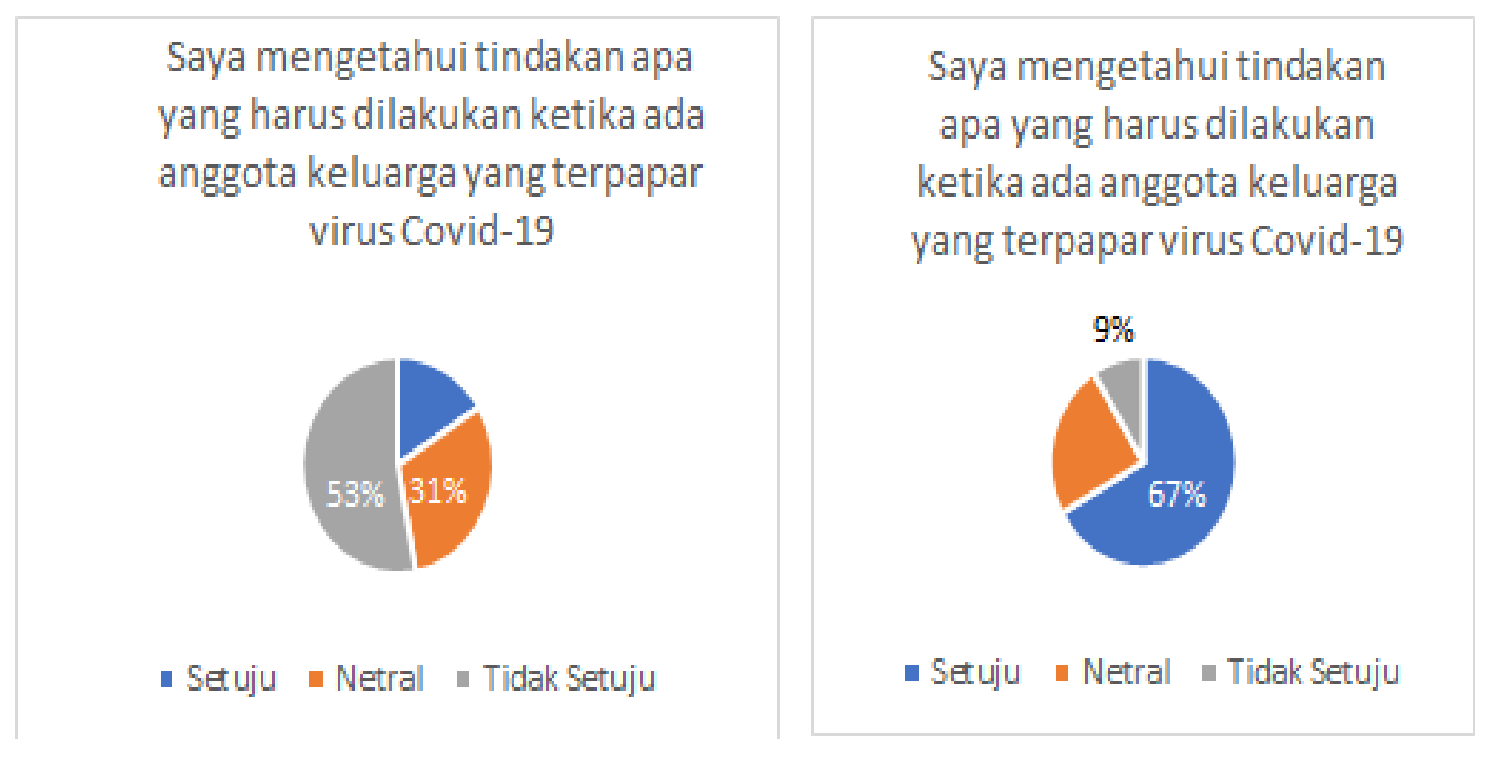

(a) Sebelum Diadakan Sosialisasi

(b) Sesudah Diadakan Sosialisasi

Sumber: Hasil Pelaksanaan (2021)

Gambar 6. Pemahaman Warga Terhadap Pengetahuan Mengenai Covid-19

Dari data-data diagram diatas, terlihat bahwa adanya peningkatan baik itu pemahaman, pengetahuan warga mengenai tindakan apa yang harus dilakukan jika salah seorang angggota keluarganya terpapar Covid-19. Hal ini disebabkan karena sebelum diadakannya sosialasasi dan penyuluhan hukum ini masyarakat awam banyak yang tidak paham dan tidak mengetahui harus melakukan apa jika ada anggota keluarganya terpapar Covid-19. Namun setelah diadakannya sosialisasi ini, mampu menjadikan masyarakat menjadi mengetahui tindakan apa yang harus dilakukan. Jadi, dapat disimpulkan, dengan diadakannya sosialisasi dan penyuluhan dapat meningkatkan pengetahuan, pemahaman serta kesadaran masyarakat terkait apa dan bagaimana proses perawatan anggota keluarga yang terpapar Covid-19. 


\section{Kesimpulan}

Covid-19 merupakan penyakit yang disebabkan oleh virus corona. Virus ini menyerang saluran pernapasan. Gejala Covid-19 yang paling umum adalah deman, kelelahan, dan batuk kering. Beberapa orang mengalami sakit dan nyeri, hidung tersumbat, pilek, sakit tenggorokan, diare. Untuk proses penularan terjadi orang ke orang sehinnga perlu adanya pencegahan yang harus dilakukan. Adapun cara penanggulangan dan pencegahan yang benar yaitu dengan selalu menjaga pola hidup sehat (makan, tidur, olahraga) untuk umunitas tubuh, rajin mencuci tangan, menjaga etika batuk dan bersin, menghindari kerumunan, menghindari menyetuh mata, mulut, dan hidung, mengurangi interaksi dengan orang lain, berdoa dan lain sebagainya. Sebagai bentuk partisipasi yang dapat yang kita lakukan yaitu dengan mendukung kebijakan pemerintah mengenai sekolah dirumah atau belajar secara online, bekerja dari rumah dan ibadah di rumah. Serta selalu melakukan hal-hal positif yang mampu mengurangi rasa khawatir terhadap maraknya penyebaran virus corona ini. Terhadap Covid-19 sebaiknya kita harus mengaplikasikan bagaimana cara penyebaran Covid-19 dalam kehidupan sehari-hari, misalnya hindari kontak langsung dari orang lain dan usahakan agar tidak keluar rumah kecuali di saat yang penting. Jangan terlalu merasa tertekan dan terbebani selama masa pandemik wabah ini, karena yang dibutuhkan adalah kuatnya system imun atau metabolisme tubuh dan dapat meningkatkan imun dengan olahraga serta makanan-makanan yang sehat. Dan maka Covid-19 ini tidak boleh disepelekan dan walaupun kita waspada jangan terlalu dipikirkan. Maka dari itu perlu adanya edukasi untuk masyarakat agar dapat memahami Covid-19 dengan adanya edukasi ini maka dapat membantu pengetahuan masyarakat terhadap Covid-19.

\section{Daftar Pustaka}

Azanella L. A. (2020). Apa itu PSBB Hingga Upaya Pencegahan Covid-19. https://www.kompas.com/tren/read/2020/04/13/153415265/apa-itu-psbbhingga-jadi-upayapencegahan-Covid-19.

Bender L. (2020). Pesan dan Kegiatan Utama Pencegahan dan Pengendalian COVID-19 di Sekolah. Publikasi UNICEF.

Bnpb.go.id. (2020). Sebaran Daerah PSBB.,https://bnpb.go.id/infografis/updatesebaran-daerahpsbb-Covid19.

Budianto, Y. (2020). Memahami Karakter Virus dan Penyakit Covi-19. https://bebas.kompas.id/baca/riset/2020/03/14/memahami-karakter-virusdan-penyakitkorona-Covid-19/.

Covid.kemkes.go.id. Status Harian Covid-19 di Indonesia. https://Covid19.kemkes.go.id/situasiinfeksi-emerging/info-corona-virus/.

Faisal, H. D., \& Susanto, A. D. (2019). Peran Masker/Respirator dalam Pencegahan Dampak Kesehatan Paru Akibat Polusi Udara. Jurnal Respirasi, 3(1), 18. https://doi.org/10.20473/jr.v3-i.1.2017.18-25 
Fatimah, I. R. (2020). Dampak Meningkatnya Harga Masker Di Tengah Mewabahnya Covid-19 Di Kalangan Masyarakat Ditinjau Dari Sudut Pandang Tindakan Manusia. https://doi.org/10.31219/osf.io/j5pn9

Gugus Tugas Percepatan Penanganan Covid-19, https://covid19.go.id/peta-sebaran.

Hapsari, K. R., \& Munawi, H. A. (2021). Pemilihan Masker Kain dalam Mencegah Penularan Virus Covid-19 Pengertian dan Dasar Hukum Pengendalian Covid19. 4(01).

World Health Organization, https://www.who.int/indonesia/news/novel-coronavirus/qa-for-public. 